\title{
The Piety of Escape
}

Phillip Shannon

ABSTRACT: This paper examines two seemingly contradictory views of piety found in Plato's Euthyphro and Crito. Using the Socratic dialogues for evidence of what Socrates actually believed and to piece together a Socratic account of piety, it seems that his argument in favor of remaining in prison is inconsistent with his own beliefs. The paper concludes that Socrates ought not to have thought it was impious to escape from prison.

While awaiting his death sentence in prison, Socrates hears many arguments attempting to convince him of the piety of escape. In Plato's Crito, Socrates gives perhaps his most explicit account of his reasons for remaining in prison. However, when his argument is examined beside a parallel argument found in Euthyphro, it seems that Socrates may have been mistaken. After reviewing the arguments, I will discuss what I believe is an inconsistency in Socrates' argument. Then, using the Socratic account of piety found in Euthyphro and evidence of his beliefs found in Euthyphro, Apology, and Crito, I will demonstrate how a faulty premise ought to be restated. Finally, I will conclude that Socrates should not have thought it would be impious to escape. It appears that when the assumptions in Socrates' arguments are restated to fit what Socrates would likely have believed in accordance with his account of piety, his life-saving escape would have been pious.

After hearing Crito's arguments in favor of escaping his death sentence, Socrates states his reasons for remaining in prison. To escape, he ar- 


\section{The Piety of Escape}

gues, would be flouting the verdicts of the city's courts, thereby decreasing the city's force. This would ultimately be harming the city. Taken to its logical conclusion, such an action would be an attempt "to destroy [the laws of Athens], and indeed the whole city." ${ }^{1}$ Socrates believes that he has special moral obligations to Athens which are similar to the obligations owed to one's parents. He personifies the laws of Athens to create a metaphor comparing his relationship with his parents to his relationship with his citystate: "[C]ould you, in the first place, deny that you are our offspring and servant, both you and your forefathers? If that is so, do you think that we are on an equal footing as regards the right, and that whatever we do to you it is right for you to do to us?"2 The conclusion is that just as a father has the right to do things to his son that his son cannot do to his father, the city has the right to do things to its subjects. "Do you think that you have this right to retaliation against your country and its laws? That if we undertake to destroy you and think it right to do so, you can undertake to destroy us, as far as you can, in return?"3 Socrates believes that, even though Athens is attempting to destroy him unjustly, he has no right to cause it harm.

Socrates then tries to demonstrate how escaping from his prison cell would be impious. "It is impious to bring violence to bear against your mother or father; it is much more so to use it against your country." 4 The argument could be stated like this:

I. It is impious to bring violence to bear against your country.

II. To escape prison would be to bring violence to bear against your country.

III. To escape prison would be impious.

Perhaps a better understanding of why Socrates believes each of these claims can be found elsewhere. Because of the analogy connecting
1. Plato, Five Dialogues, trans. G. M. A. Grube (Indianapolis: Hackett, 2002): 53.
2. Ibid.
3. Ibid., 54 .
4. Ibid. 
one's relationship with his parents to his relationship with his country, this argument runs parallel with the one being refuted by Euthyphro: ${ }^{5}$

I. It is impious to bring violence to bear against your father.

II. Euthyphro is prosecuting his father for murder, thereby bringing violence to bear against his father.

III. Euthyphro is doing something impious.

Euthyphro denies the impiety of his actions. He believes that this argument is one of the misguided masses, and that "the pious is [...] to prosecute the wrongdoer, be it about murder or temple robbery or anything else, whether the wrongdoer is your father or your mother or anyone else; not to prosecute is impious." ${ }^{\prime 6}$ However, at the end of the dialogue, Euthyphro has still given no real reason why what he is doing is not impious. Socrates states that if Euthyphro had "no clear knowledge of piety and impiety," he would have never "ventured to prosecute [his] father for murder on behalf of a servant." 7 We can thus hold Socrates to the claim that, when the piousness of an action is in question, the default position is to regard the action as impious unless one has a good reason to believe otherwise. With no such reasons, it is practical to believe that Euthyphro is doing something impious.

The first premise of the parallel arguments, restated as "It is impious to bring violence to bear against your country or father," is problematic. Socrates gives evidence in the Apology that there are cases in which it is permissible to bring violence to bear against your country. When Athens was ruled by the Thirty, Socrates was ordered to bring in Leon from Salamis to be executed. Believing this execution to be unjust, Socrates did not follow the order. He argues that, in making that decision, his "whole concern [was] not to do anything unjust or impious." ${ }^{8}$ Because he is disobey-

5. Ibid., 5.

6. Ibid., 6.

7. Ibid., 20.

8. Ibid., 37. 


\section{The Piety of Escape}

ing the laws of his country, Socrates is "bringing violence to bear against his country." We are presented with the following inconsistent triad in Socrates' reasoning:

I. It is impious to bring violence to bear against your country or father.

II. Socrates disobeyed an order, thereby bringing violence to bear against his country.

III. Socrates has not done anything impious.

At most, only two of these statements can be true. The most likely proposition to be correct is (II). Socrates did disobey an order, and, even if only to a small degree, this means that he brought violence to bear against his country.

Whether or not (III) is true depends largely on the account of piety one chooses. Because we are examining Socrates' own argument, it is appropriate to use his account of piety. When Socrates refused to follow the orders of the Thirty, it is unclear whether he did it because he believed complying would be unjust or because complying would be impious, or both. He does not make it any clearer when he states, "[D]eath is something I couldn't care less about, but that my whole concern is not to do anything unjust or impious." ${ }^{9}$ Gregory Vlastos examines this in depth as he points to two doctrines that Socrates claims loyalty to in his actions. One is the reasoned argument; "I am the kind of man who listens to nothing within me but the argument that on reflection seems best to me," ${ }^{10}$ while the other is the divine, which can be found in his explanation to the court of his pursuit of philosophy as being "enjoined upon [him] by the god, by means of oracles and dreams, and in every other way that a divine manifestation has ever ordered a man to do anything." 11

11. Gregory Vlastos, Socrates, Ironist and Moral Philosopher (Ithaca: Cornell University Press, 1991): 157. 
By openly committing himself to these two philosophies, reasoned argument and the divine, Socrates is accepting ideas that could be conflicting. Vlastos compares Socrates' rationalization of the gods with the way the Ionians rationalized the gods. The Ionians had a world in which the existence of "gods" was unnecessary, but if they existed, they would be "naturalized and thereby rationalized."12 This merges the idea of god with ideas from science of nature, physiologia. Any Ionian gods would therefore have the same naturalistic limitations as man. Vlastos argues that Socrates rationalizes the gods in a similar manner, but instead of holding them to naturalist principles, he holds them to the same moral principles as man.

Vlastos' most convincing piece of evidence for this comes from book II of the Republic. While it is likely that the Republic was written in Plato's middle period, in which it is generally thought that Plato began expressing his own ideas rather than those of Socrates, and while what follows this passage is clearly Platonic, Vlastos points out that this section does not use "any premises foreign to the thought of the earlier dialogues:"13

\footnotetext{
"What about what is good? Is it beneficial? [Yes.] So it is the cause of doing well? [Yes.] What is good is not the cause of all things, then. Instead, it is the cause of things that are good, while the bad ones it is not the cause. [Exactly.] Since the gods are good, they are not - as the masses claim - the cause of everything. Instead, they are a cause of only a few things that happen to human beings, while of most they are not the cause. For good things are fewer than bad ones in our lives. Of the good things, they alone are the cause, but we must find some other cause for the bad ones, not the gods." 14
}

12. Ibid., 159.

13. Ibid., 163.

14. Plato, Republic, trans. C. D. C. Reeve (Indianapolis: Hackett, 2004): 60. 


\section{The Piety of Escape}

"Socrates, no metaphysician, sticking to his own last, the moralist's, taking the fact of such causation [of the good] for granted, is content to do no more than clamp on it moral constraints, reasoning that since the gods are good, they can only cause good, never evil." ${ }^{15}$ The Greek gods were often credited with superior wisdom, and Vlastos argues that Socrates held this to be true, too. For Socrates, however, this superior wisdom was "not theoretical, but practical," and because of the way he has rationalized the gods this "wisdom binds gods no less than men."16

Because Euthyphro ended in aporia, a Socratic account of piety may seem out of reach. Despite this, to define Socratic piety, Vlastos believes we need only to look at the evidence found in Euthyphro and the Apology. Upon hearing Euthyphro characterize piety as "the godly and pious is the part of the just that is concerned with the care of the god," Socrates asks, "To the achievement of what aim does service to the gods tend?"17 Vlastos points out that Socrates tells Euthyphro how important a question this is when he states, "if you had given that answer, I should now have acquired from you sufficient knowledge of the nature of piety."18 While Euthyphro still does not have an answer for Socrates after this comment, by examining the Apology we can infer what Socrates' own response to that question would be. Vlastos argues that Socrates saw his own work as pious, as it was "his own service to the god" by "summoning all and sundry to perfect their soul [...] at the god's command."19 This point of view is supported by Socrates' claim in the Apology that he "was attached to [Athens] by the god [in order to] fulfill some such function," ${ }^{20}$ namely to talk to the people of Athens and "[persuade them] to care for virtue." ${ }^{21}$ Taking these things into account, Vlastos believes that Socrates' account of piety can be sum-

\footnotetext{
15. Vlastos, Socrates, Ironist and Moral Philosopher, 163.

16. Ibid., 164.

17. Plato, Five Dialogues, 17.

18. Vlastos, Socrates, Ironist and Moral Philosopher, 174.

19. Ibid., 175.

20. Plato, Five Dialogues, 35.

21. Ibid.
} 
marized like this: "doing on the god's behalf, in assistance to him, work the god wants done and would be doing himself if he only could."22

Applying this account of piety to (III) of the aforementioned inconsistent triad, we can assume that Socrates would have agreed that (III) is correct. Because he was working on the gods behalf, and because he had rationalized his god as being restricted by the same moral principles as his own, Socrates could not have justified doing something obviously impermissible like leading Leon of Salamis to his execution. With this in mind, there seem to be no good reasons to doubt (II) or (III). The only proposition left to be rejected is (I). If Socrates denies that it is impious to bring violence to bear against your country or father, then what does he actually believe? I have already shown that Socrates believes that Euthyphro's prosecution of his father is impious, so it is impious in at least some cases to bring violence to bear against your country or father. Therefore, Socrates' actual position must admit both cases in which it is impious and cases in which it is not impious to bring violence to bear against one's country.

Because of this, there must be at least one significant difference between Euthyphro's case and Socrates' case with the Rule of Thirty. In the Rule of Thirty case, Socrates objects to what he is being ordered to do because it is obviously unjust. He states that he would rather be "on the side of law and justice" than take part in "an unjust course."23 "That government, powerful as it was, did not frighten me into any wrongdoing." ${ }^{24}$ While it is not completely certain that what Euthyphro is doing is impious, there is no reason given to believe otherwise. At the very least, we can say that a crucial difference between these two is that one involves engaging in an action which is certainly unjust, while the other involves engaging in an action which is possibly, but not necessarily, unjust. Since this appears to me to be the only significant difference between these two cases, Socrates' position is likely to be that it is not impious to bring violence to bear

22. Vlastos, Socrates, Ironist and Moral Philosopher, 175.

23. Plato, Five Dialogues, 36.

24. Ibid., 37. 


\section{The Piety of Escape}

against your country just in case you would be doing something obviously unjust by doing otherwise.

Using this as a premise to replace Socrates' original inconsistent belief, we can now reexamine the original argument about why he should not attempt to escape prison:

I. It is impious to bring violence to bear against your country unless doing otherwise would be engaging in something obviously unjust.

II. To escape prison would be to bring violence to bear against your country.

III. To escape prison would be impious.

The conclusion in this adaptation of the original argument does not necessarily follow from the first two premises. If it can be shown that Socrates would be doing something obviously unjust by "doing otherwise," namely staying in prison, there would be two significant implications. The first is that Socrates would be engaging in an unjust action by remaining in prison. The second is the rejection of the conclusion, thus demonstrating that escaping from prison would not be an impious form of bringing violence to bear against one's country.

The impiety of Socrates escaping prison depends on whether or not he would be doing something obviously unjust by remaining there. Crito gives several arguments in favor of this. The first is that it is unjust for Socrates to "give up [his] life when [he] can save it." 25 This is not always true. If I am on a sinking ship and can save myself but only by tipping over and killing a lifeboat full of people, it would be unjust to save my life. Another argument from Crito is that Socrates is doing something unjust by doing something which would "hasten [his] fate as [his] enemies would hasten

25. Ibid., 48 . 
it." ${ }^{26}$ This does not provide a good enough reason to believe that Socrates is doing something unjust by remaining in prison because there are examples which show that a just action is one which hastens someone's fate as his enemies would. For example, a prisoner who has been justly and rightly convicted but has escaped authorities would be doing a just thing by turning himself in, while at the same time also hastening his fate as his enemies would.

At this point, it could be reasonably objected that if Socrates believed it is worse to do wrong than to be wronged, thus my argument has yet to go far enough. However, one could respond to this objection by examining Crito's argument that Socrates would be aiding the city in doing something unjust, and therefore doing something obviously unjust. If one accepts that supporting an unjust action is wrong, and he also accepts that the sentence is unjust, then he must also believe that submitting to the sentence is unjust just in case there are practical alternative options available. ${ }^{27}$ Socrates clearly believes that Athens has done something unjust, which he expresses by his warning the city of its oncoming guilt for killing him, ${ }^{28}$ and by pointing out that his accusers are "condemned by truth to wickedness and injustice. ${ }^{\prime 29}$ Crito argues that sitting in prison hastens the unjust sentence and helps in carrying it out, thereby making Socrates a guilty party in his own death sentence. If Socrates would have attempted escape, it seems clear that there would have been very little resistance by the city. The amount of harm done, if any, is almost certainly less than the amount of harm done by complying in the murder of a man who was unjustly convicted. Thus, Crito's argument makes it clear that Socrates would be doing something obviously unjust by remaining in prison.

Upon reaching this conclusion, we can reexamine Socrates' argument for escape one last time with the new premise that Socrates is doing something obviously unjust by remaining in prison.

\footnotetext{
26. Ibid.

27. Ibid.

28. Ibid., 42.

29. Ibid.
} 


\section{The Piety of Escape}

I. It is impious to bring violence to bear against your country unless doing otherwise would be engaging in something obviously unjust.

II. To escape prison would be to bring violence to bear against your country.

III. Socrates would be doing something obviously unjust by remaining in prison.

The conclusion that could logically be deduced is this:

IV. Socrates' escape from prison is not a case of impious violence against one's country.

That does not confirm Socrates' escape from prison is not impious, but only that it is not impious in the sense that it is impious to bring violence to bear against your country. It could still be a possibility that his escape is unjust for other reasons. However, it seems that there are no other reasons given in Plato's writing, and we can therefore conclude that Socrates' escape from prison would not be impious.

I would like to thank the anonymous referees for raising the objection that it is possible that Socrates respects procedural justice. If Socrates believed that one has an obligation to a just government to obey its decisions, then this would account for the significant difference between Socrates' refusal to cooperate with the Rule of Thirty and his unwavering decision to comply with his death sentence. While this may seem like a reasonable interpretation of Socrates' behavior at first glance, evidence from the Apology suggests otherwise. Had the Athenian court said to Socrates, "We acquit you, but only on condition that you spend no more time on this investigation and do not practice philosophy, and if you are caught doing so you will die, '"30 Socrates would have had to respect and comply with

30. Ibid., 34 . 
this decision. Surely, this is no less just than his death sentence. Despite this, Socrates confesses that he would never follow such a decision: "As long as I draw breath and am able, I shall not cease to practice philosophy." ${ }^{131}$ This provides a contradiction for any claim that Socrates' respect for the procedural justice of Athens is what held him in prison.

Why would Socrates comply with a death sentence but not with an order to cease practicing philosophy? If his account of piety is "doing on the god's behalf, in assistance to him, work the god wants done and would be doing himself if he only could"32 requires that he practice philosophy, and to escape prison would mean he would never be allowed to practice philosophy, then it is possible that Socrates could never justify this type of life as not being impious. Because "the unexamined life is not worth living, ${ }^{\prime 33}$ perhaps death appeared to be the best alternative. In spite of this, I believe that Socrates is doing something much worse by accepting his death sentence: giving up on his gods-given mission. While it is likely that he would be put to death for acting in a way that he believes is pious, surely it would be more pious to escape prison and continue practicing philosophy than to accept death and never practice philosophy in Athens again.

I have thus shown why I believe Socrates' argument to remain in prison to be unsound. One premise of it appears to be inconsistent with Socrates' own beliefs and actions. Using Socrates' account of piety, if all actions which brought harm to bear against your country were impious, then Socrates would have been doing something impious by not obeying the Rule of Thirty order to capture Leon of Salamis. However, it seems clear that Socrates also believes that Euthyphro was doing something impious by prosecuting his father. Modifying the premise to accommodate these two seemingly contradictory cases, it appears his argument that escaping prison is impious was insufficient. Because Socrates believed his sentence

31. Ibid.

32. Vlastos, Socrates, Ironist and Moral Philosopher, 175.

33. Plato, Five Dialogues, 41. 


\section{The Piety of Escape}

was unjust, he could not reasonably deny Crito's argument that he is engaging in something unjust by remaining in prison. After examining an objection about the nature of Socrates' reasons for remaining in prison, I have not been given cause to doubt my position. I have ultimately concluded that Socrates would have not been doing something impious by escaping prison. 